\title{
Production of Refractory Porcelain Crucibles from Local Ceramic Raw Materials using Slip Casting
}

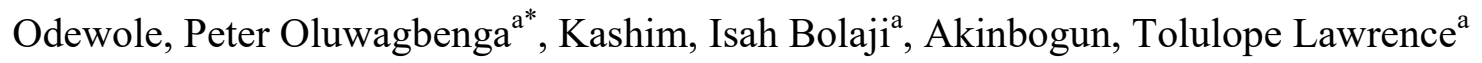 \\ ${ }^{a}$ Federal University of Technology, Akure, 340252,Ondo State, Nigeria.
}

Received: 20 May 2019; Accepted: 12 June 2019; Published: 08 September 2019

\begin{abstract}
The vast need for refractories in Nigeria makes it imperative to domesticate its production in the country in order to reduce over-reliance on their importation. In this research, refractory porcelain crucibles were produced from indigenous ceramic raw materials from Ikere Ekiti and Awo (locations in South Western, Nigeria). Chemical analysis was carried out on the raw materials using X-ray Fluorescence Spectrometer (XRF) to determine their chemical compositions. Five body compositions, labeled as samples A-E were formulated and the crucibles were produced using slip casting. They were dried and fired in a gas kiln up to $1300^{\circ} \mathrm{C}$ for 6 hours. The result of the standard tests carried out on the locally produced porcelain crucibles showed total shrinkage of $10 \%-15 \%$, water absorption of $0.36 \%-0.72 \%$, compressive strength of $1.43 \mathrm{~N} / \mathrm{mm}^{2}-1.65 \mathrm{~N} / \mathrm{mm}^{2}$ and refractoriness of $1680.2^{0} \mathrm{C}-1717.5^{\circ} \mathrm{C}$. The result showed that ceramic raw materials sourced from the selected deposits in South Western Nigeria are suitable for the production of porcelain crucibles with good refractory properties.
\end{abstract}

Index Terms: Refractories, Porcelain Crucibles, Mullite, Ceramic Raw Materials, Local Production.

(C) 2019 Published by MECS Publisher. Selection and/or peer review under responsibility of the Research Association of Mode rn Education and Computer Science

\footnotetext{
* Corresponding author.

E-mail address: peterodewole@gmail.com
} 


\section{Introduction}

A refractory material is one that can withstand the action of abrasive or corrosive solids, liquids or gases at a high service temperature [1]. Crucibles are open mouth vessels used for high temperature reactions [2]. The use of crucibles and other refractories for pyro-technological applications has made them of utmost benefit towards technological development from ancient times to the present. According to [3], no metallurgy could have emerged in man's early history without the knowledge of refractory ceramics for use in moulds, furnaces and crucibles. This implies that, without the discovery of ceramic refractories such as crucibles, metal production and metal products would not have been possible. Ceramic crucibles have been used for working with metals since around $5000 \mathrm{BC}$ [4]. This does not suggest that the use of ceramic crucibles is only limited to metallurgy as its utmost significance in glass and ceramic processing cannot be overemphasized.

The term porcelain refers to a wide range of ceramic products that have been fired at high temperature to achieve vitreous or glassy qualities such as translucence and low porosity [5]. Porcelain is a ceramic material made by heating ceramic raw materials, generally including clay in the form of kaolin, in a kiln to temperatures between $1,200^{\circ} \mathrm{C}$ and $1,400^{\circ} \mathrm{C}$ [6]. High thermal shock resistance of porcelain crucibles is attributed to the presence of mullite / or cordierite structures [7]. Hence, porcelain crucibles are classified as mullite crucibles. They are used in induction furnaces for melting glass and metals and in most cases suggested for safe use up to $1700^{\circ} \mathrm{C}[8,9]$.

Nigeria, being a developing nation, has a potentially enormous need for refractories [10]. For instance, refractory crucibles are grossly needed in metallurgical, glass and ceramic industries for metal and alloy melting, glassmelting and frit-processing among others. [11] observed that huge savings could be obtained if local raw materials are properly exploited and harnessed towards the production of refractories. The reason is that importation is not healthy for the country's economy owing to unfavourable foreign exchange rate. In this regards, [12] observed that in the last few years, there has been an increasing awareness on the scope, and the importance of refractory materials in the industrial development of Nigeria. Unfortunately, there is no major specialized refractory industry in Nigeria despite the fact that there are abundant deposits of these rocks in the country [13]. There exists a good investment opportunity for the local production of crucible in the country [14].

[15] produced refractory pots using kaolin from Kankara in Katsina State (Northern Nigerian) and ball clay from Bomo village, Kaduna State (Northern Nigeria). [16] produced high temperature crucible using kaolin from Kankara and ball clay from Bomo, Zaria in Kaduna State. [14] produced crucible using aluminosilicate clay from Kankara and baggasse ash. There seems not to be much research efforts channeled towards investigating into suitability of using locally sourced ceramic materials from South Western Nigeria for refractories production. This study aims to fill this gap. To this ends, this research was focused on the production of refractory crucibles from the locally available ceramic raw materials in South Western Nigeria. It is hoped that exploiting the available underutilized ceramic resources in the country for the purpose of producing refractories such as porcelain crucibles would reduce the cost spent on the importation of foreign-made refractories into the country, encourage the development of local refractory industries that would replicate its production in mass and provide job for the teeming unemployed Nigerian youths, thereby sustaining Nigeria economy.

The continuing part of this study is structured as follow: Section 2 reviews pertinent literature on the thermodynamic phase system of aluminosilicate materials at high temperatures, the relative abundance of the needed raw materials for the study within the study areas located in South Western Nigeria and the significance of these ceramic raw materials to the production of refractory porcelain crucibles. Section 3 presents the materials, equipment, and methods used in achieving the objectives of the study. Section 4 
presents the results and discussion based on the findings in the study. The last section presents the conclusion derived from the outcome of the study.

\section{Literature Review}

Mullite $\left(3 \mathrm{Al}_{2} \mathrm{O}_{3} \cdot 2 \mathrm{SiO}_{2}\right)$ is a unique thermodynamically stable phase in the binary system of the aluminosilicates [17]. It is thus an important component of the high-temperature bonding phase in refractories, whitewares and structural clay products [18]. Mullite is suitably used for high-temperature structural ceramics due to its excellent physical properties such as low dielectric constant, low thermal expansion, high melting point, high creep resistance, high resistance to chemical corrosion, high temperature mechanical stability, and thus high thermal shock resistance [19]. [7] asserted that formulation mixture of porcelain crucibles should be fired up to $1300^{\circ} \mathrm{C}$ or more as alumina $\left(\mathrm{Al}_{2} \mathrm{O}_{3}\right)$ in the raw materials reacts with silica $\left(\mathrm{SiO}_{2}\right)$ at this temperature to form mullite. Figure 1 shows typical ceramic phase diagram of $\mathrm{SiO}_{2}-\mathrm{Al}_{2} \mathrm{O}_{3}$ system with the formation of mullite as an intermediate compound.

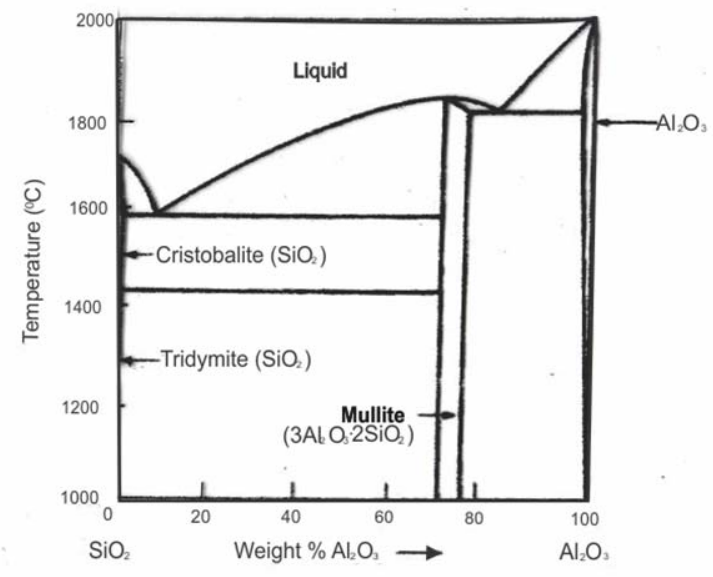

Fig. 1. Phase diagram of $\mathrm{SiO}_{2}-\mathrm{Al}_{2} \mathrm{O}_{3}$ binary system.

Ceramic raw materials suitable for refractories production are abundantly available in various locations across Nigeria. However, these ceramic resources have been underutilized [20, 21]. The choice of locations for sourcing ceramic raw materials used in this study was necessitated by some criteria which include proximity to the area of study, availability in relative abundance and their suitability for use as revealed by their chemical composition. Initial information on these criteria was obtained from available literatures. The estimated reserve of kaolin deposit in Ikere Ekiti was found to be at approximately 2,732,305 tonnes with the excavable volume of 219,819 cubic meters [22]. Table 1 shows the chemical composition of Ikere kaolin and ball clay as investigated by [23] and Awo quartz as investigated by [24] respectively.

The relevance of the ceramic raw materials used in this study to the production of refractory porcelain crucibles is given as follows:

(a) Kaolin

[25] observed that kaolin is the principal raw material needed for the production of technical ceramic items such as refractory crucibles as it gives plasticity to enable the body to be shaped, giving adequate unfired strength so that it may be handled between the shaping and firing process. Kaolin is used in refractories due to its extremely high fusion point, low water content and high green strength [26]. 
Table 1. Chemical composition of Ikere Ekiti Kaolin and Ball Clay

\begin{tabular}{|c|c|c|c|c|c|c|c|c|c|}
\hline & $\mathrm{SiO}_{2}$ & $\mathbf{A l}_{2} \mathbf{O}_{3}$ & $\mathrm{Fe}_{2} \mathrm{O}_{3}$ & MgO & $\mathrm{CaO}$ & $\mathrm{Na}_{2} \mathrm{O}$ & $\mathbf{K}_{2} \mathbf{O}$ & $\mathrm{TiO}_{2}$ & L.O.I. \\
\hline Ikere Ekiti kaolin $^{\mid 23]}$ & 46.38 & 36.1 & 0.58 & 0.07 & 0.05 & 0.86 & 0.46 & 0.72 & 13.07 \\
\hline Ikere Ekiti Ball Clay $^{[23]}$ & 57.82 & 32.4 & 2.21 & 0.07 & 0.37 & 0.41 & 2.33 & 1.8 & 7.24 \\
\hline Awo Quartz ${ }^{[24]}$ & 71.92 & 15.4 & 1.18 & 0.19 & 0.99 & 5.28 & 3.59 & - & - \\
\hline
\end{tabular}

(b) Quartz

Addition of quartz makes a clay body more refractory and opens up the body, thereby reducing shrinkage and drying problems [27]. [28] observed that quartz enhances strength to the refractory ware and it is active in reducing plasticity and shrinkage. [27] however, observed that items exposed to sudden temperature changes such as crucibles should contain as little free silica as possible. This is owing to the fact that some silica contract and expand and contract suddenly at certain temperature.

(c) Ball Clay

Ball clay is essential because of its high plasticity and strength. Clay is added to the ceramic body in order to enable bindability of the non-plastic materials. An addition of about $10 \%$ plastic clay will solve the problem of lack of plasticity and difficulty of a clay body to be formed into shapes [27].

(d) Calcined kaolin

Calcined kaolin or metakaolin is an anhydrous aluminium silicate produced by heating natural kaolin to high temperatures. The process of converting kaolin into metakaolin is known as metakaolinization or dehydroxylation. Metakaolin contains high content of $\mathrm{Si}$ and $\mathrm{Al}$ and is obtained by heating (calcinating) kaolin raw material. The calcination process occurs at temperatures ranging from $\approx 450{ }^{\circ} \mathrm{C}$ to $\approx 750^{\circ} \mathrm{C}$ promotes the removal of the structural water (dehydroxylation) in kaolinite and its transformation into metakaolinite that is an amorphous (disordered) aluminosilicate; calcination at higher temperature $\left(>950^{\circ} \mathrm{C}\right)$ results in the formation of crystalline phases, such as silicon-spinel or mullite [29]. Thermal history of calcined kaolin is as shown in Figure 2. The chemical equation describing the process of transformation of kaolin into metakaolin is:

$$
\begin{gathered}
\mathrm{Al}_{2} \mathrm{O}_{3} \cdot 2 \mathrm{SiO}_{2} \cdot 2 \mathrm{H}_{2} \mathrm{O}(\mathrm{s}) \text {---------- } \\
\text { kaolin } \\
\mathrm{Al}_{2} \mathrm{O}_{3} \cdot \mathrm{SiO}_{2}(\mathrm{~s})+\underset{\text { metakalin }}{2 \mathrm{H}_{2} \mathrm{O}(\mathrm{g})}
\end{gathered}
$$

Calcined kaolin is also being referred to as kaolin grog. Grogs generally are added to bodies to improve drying performance, reduce drying shrinkage, improve fired abrasion resistance, reduce thermal expansion, reduce fired shrinkage, reduce density and impart visual character [30].

\section{Materials, Equipment and Methods}

\subsection{Materials}

The raw materials used in this study include kaolin, quartz, calcined kaolin and ball clay. Kaolin and ball clay were sourced in situ from Ikere Ekiti in Ekiti State. Quartz was sourced in situ from Awo, Osun State. 


\subsection{Equipment}

The equipment for this study includes the following: X-ray Fluorescence spectrometer, gas kiln, throwing wheel, mortar and pestle, sledge hammer, electronic weighing machine, set of standard sieves, POP mould, plastic drum, rolling pin, and pulverizer.



Fig. 2. Thermal history of calcined kaolin [31]

\subsection{Method}

Kaolin and ball clay were each soaked, sieved and dried. Part of the dried kaolin was calcined in a gas kiln to $10000 \mathrm{C}$ for 6 hours. The resulting raw material, kaolin grog, was crushed, ground and sieved through $600 \mu \mathrm{m}$ and $300 \mu \mathrm{m}$ mesh British Standard Sieve. Quartz was thoroughly washed to remove physically combined impurities, dried and was calcined at $1000^{\circ} \mathrm{C}$ for 6 hours in a gas kiln. It was allowed to cool and was then manually crushed into pieces using a sledge hammer. It was further broken into smaller grains with the aid of the pulverizer after which it was sieved through $150 \mu \mathrm{m}$ and $75 \mu \mathrm{m}$ mesh British Standard Sieve. After beneficiation and processing, the samples of the sourced raw materials were analyzed using X-ray Fluorescence Spectrometer. The result of the X-ray Fluorescence spectrometry analysis of the raw materials obtained at The National Geosciences Research Laboratories, Kaduna is as shown in Table 2.

Five body compositions were formulated as shown in Table 3. The model was made with ball clay using the throwing wheel. The mould was made using plaster of Paris and was allowed to dry in the sun. Each batch as shown in Table 3 was weighed separately according to its percentage weight. $2000 \mathrm{~g}$ of each of the batches was slaked with 1.5 litres of water and was thoroughly mixed in order to allow even distribution of particles in the ceramic body. Slip casting method was used to produce the crucibles. The formed crucibles were kept to dry slowly at room temperature. This was done in order to keep the drying rate of the crucibles at minimum in order to avoid cracking. 
Table 2. Chemical compositions of Ikere Ekiti Clays and Awo Quartz

\begin{tabular}{lllll}
\hline Chemical & $\begin{array}{l}\text { Ikere Ekiti } \\
\text { Kaolin }\end{array}$ & $\begin{array}{l}\text { Ikere Ekiti } \\
\text { Calcined Kaolin }\end{array}$ & $\begin{array}{l}\text { Ikere Ekiti } \\
\text { Ball Clay }\end{array}$ & Awo Quartz \\
\hline $\mathbf{S i O}_{2}$ & 58.6 & 52.8 & 61.9 & 98.69 \\
$\mathbf{A l}_{2} \mathbf{O}_{3}$ & 32.3 & 46.8 & 19 & - \\
$\mathbf{F e}_{2} \mathbf{O}_{3}$ & 1.21 & 0.07 & 6.86 & 0.073 \\
$\mathbf{M g O}$ & - & - & 0.08 & - \\
$\mathbf{C a O}$ & - & - & 0.87 & 0.455 \\
$\mathbf{N a} \mathbf{O}_{2} \mathbf{O}$ & 0.86 & 0.02 & 0.62 & 0.01 \\
$\mathbf{K}_{2} \mathbf{O}$ & 3.46 & 0.19 & 4.4 & 0.11 \\
$\mathbf{M n O}$ & 0.027 & 0.01 & 0.14 & 0.01 \\
$\mathbf{T i O}$ & 0.11 & 0.01 & 2.01 & 0.71 \\
$\mathbf{L . O}$ & 3.4 & & 3.68 & \\
\hline
\end{tabular}

Table 3. Formulated Ceramic Bodies for Crucible Making

\begin{tabular}{llllll}
\hline & $\begin{array}{l}\text { A } \\
(\mathbf{w t} \%)\end{array}$ & $\begin{array}{l}\text { B } \\
(\mathbf{w t} \%)\end{array}$ & $\begin{array}{l}\mathbf{C} \\
\mathbf{( w t )}\end{array}$ & $\begin{array}{l}\mathbf{D} \\
\mathbf{( w t \% )}\end{array}$ & $\begin{array}{l}\mathbf{E} \\
\mathbf{( w t} \%)\end{array}$ \\
\hline Ball Clay & 10 & 20 & 30 & 10 & 10 \\
Kaolin & 50 & 40 & 30 & 40 & 30 \\
Calcined kaolin & 30 & 30 & 30 & 40 & 50 \\
Quartz & 10 & 10 & 10 & 10 & 10 \\
\hline
\end{tabular}

They were then dried in an electric oven at $110^{\circ} \mathrm{C}$ for 24 hours. The dried crucibles were loaded in a gas kiln. Preheating was done for three (3) hours so as to prevent the crucibles from breakage in the course of thermal transformation. The firing was then gradually increased at intermittent intervals, slowly at first and was later increased to the full firing stage. The crucibles were fired up to $1300^{\circ} \mathrm{C}$ for 6 hours.

\subsubsection{Determination of total shrinkage}

Drying shrinkage depends on the fineness and plasticity of the raw clay. Total shrinkage indicates the degree of vitrification of the clay or clay body at the temperature at which it has been fired. The plastic length of each of the test pieces was measured and after fully dried, the drying length was also measured. It was then fired in a gas kiln for 6hours to $1300^{\circ} \mathrm{C}$ after which the total shrinkage was measured. The total shrinkage was calculated according to [6], where $\mathrm{Lw}=$ wet length, and $\mathrm{Lf}=$ fired length.

Total Shrinkage $=\mathrm{L}_{\mathrm{w}}-\mathrm{L}_{\mathrm{f}} \times 100 \% / \mathrm{L}_{\mathrm{w}}$ 


\subsubsection{Determination of Water Absorption}

Water absorption is one of the properties that are widely used in the evaluation and comparison of product quality as part of the criteria for selection and use of refractory products in a variety of industrial applications. Water absorption test was conducted by boiling the fired test pieces at $100^{\circ} \mathrm{C}$ for 2 hours, followed by an additional soaking in water for 4 hours. Water absorption was calculated as a function of the sample's weight difference prior to and after water submersion using the formula according to [23], where Ws $=$ soaked weight and $\mathrm{Wd}=$ dry weight.

$$
\text { Water Absorption }=\mathrm{W}_{\mathrm{s}}-\mathrm{W}_{\mathrm{d}} \times 100 \% / \mathrm{W}_{\mathrm{d}}
$$

\subsubsection{Compressive Strength Test}

The dimensions of the produced porcelain crucibles were measured using the metre rule. The mass of the fired porcelain crucibles were also weighed when cold. Porcelain crucible samples were placed on a compressive machine. Load was applied at a uniform rate on the crucibles until they were crushed. The manometer readings were recorded. The compressive strength was calculated using the equation according to [23], where $\mathrm{L}_{\max }=$ maximum load and $\mathrm{A}=$ cross sectional area of the porcelain crucibles.

Compressive Strength $=\mathrm{L}_{\max } / \mathrm{A}$

\subsubsection{Refractoriness}

Refractoriness is the ability a refractory material to withstand high temperatures without fusion or decomposition. The refractoriness of the refractory crucible was estimated using Shuen's formula adapted from [32], where, $\mathrm{K}=$ Refractoriness $\left({ }^{\circ} \mathrm{C}\right), \mathrm{Al}_{2} \mathrm{O}_{3}=$ Alumina content in the raw materials, $\mathrm{RO}=$ Sum of all the oxides beside $\mathrm{SiO}_{2}$ in the raw materials, 360 and 0.228 are constants.

$$
\mathrm{K}=360+\mathrm{Al}_{2} \mathrm{O}_{3}-\mathrm{RO} / 0.228
$$



Fig. 3. The crucible in the plaster mould produced using slip casting 




Fig. 4. Slip-cast crucible detached from the plaster mould



Fig. 5. The produced refractory porcelain crucibles

\section{Results and Discussion}

From Table 1, it is observed that kaolin contained 58.6\% silica $\left(\mathrm{SiO}_{2}\right), 32.3 \%$ alumina $\left(\mathrm{Al}_{2} \mathrm{O}_{3}\right), 3.46 \%$ potassium oxide $\left(\mathrm{K}_{2} \mathrm{O}\right)$ and $0.86 \%$ sodium oxide $\left(\mathrm{Na}_{2} \mathrm{O}\right)$ respectively. The coloured oxides present are $0.027 \%$ manganese oxide $(\mathrm{MnO}), 0.11 \%$ titanium oxide $\left(\mathrm{TiO}_{2}\right)$ and $1.21 \%$ iron (III) oxide $\left(\mathrm{Fe}_{2} \mathrm{O}_{3}\right)$ respectively. Table 4 shows the comparison of chemical composition of Ikere kaolin with Kankara kaolin from three different sources. It is clear that compared to Kankara kaolin which has been ascertained by different researchers as a good aluminosilicate material suitable for refractories production, Ikere Ekiti kaolin show the quality of good aluminosilicate materials with relatively high percentage of silica and alumina and low impurities (coloured oxides). The high content of silica in Awo quartz shows significantly high level of purity of the material. It can thus be inferred that Awo quartz and Ikere Ekiti ball clay are good raw materials suitable for the production of aluminosilicate refractories. The observation of the physical appearance of the produced crucibles is as shown in Table 5. 
Table 4. Comparison of Chemical Composition of Ikere kaolin with Kankara kaolin from different sources.

\begin{tabular}{llllllllllll}
\hline & $\mathrm{SiO}_{2}$ & $\mathrm{Al}_{2} \mathbf{O}_{3}$ & $\mathrm{Fe}_{2} \mathbf{O}_{3}$ & $\mathbf{M g O}$ & $\mathbf{C a O}$ & $\mathbf{N a}_{2} \mathbf{O}$ & $\mathbf{K}_{2} \mathbf{O}$ & $\mathbf{T i O}_{2}$ & $\mathbf{M n O}$ & $\mathbf{P}_{2} \mathbf{O}_{5}$ & L.O.I. \\
\hline Kankara 1 $^{[15]}$ & 44.55 & 31.45 & 1.07 & 0.87 & 0.28 & 0.17 & 0.03 & 0.41 & 0.01 & - & - \\
Kankara 2 $^{[33]}$ & 47.30 & 36.80 & 0.71 & 0.16 & 0.08 & 0.05 & 1.01 & 0.16 & - & - & 14.81 \\
Kankara 3 3 $^{[14]}$ & 46.48 & 36.40 & 1.09 & 0.87 & 0.73 & - & 0.10 & - & - & 0.02 & 14.31 \\
Ikere Ekiti $^{[23]}$ & 46.38 & 36.10 & 0.58 & 0.07 & 0.05 & 0.86 & 0.46 & 0.72 & - & - & 13.07 \\
Ikere Ekiti $^{\left[{ }^{*}\right]}$ & 58.60 & 32.30 & 1.21 & - & - & 0.86 & 3.46 & 0.11 & 0.027 & - & 3.43 \\
\hline
\end{tabular}

*Authors' research work.

Table 5. Physical appearance of the produced crucibles

\begin{tabular}{cl}
\hline Porcelain crucible sample & Physical appearance \\
\hline A & creamy white \\
B & brownish white \\
C & burnt white \\
D & off white \\
E & off white \\
\hline
\end{tabular}

High percentage of Ikere Ekiti ball clay in sample B and C could have been responsible for the brownish white and burnt white colour respectively. This can be traceable to the high amount of coloured oxides of transition metals such as $\mathrm{Fe}_{2} \mathrm{O}_{3}(6.86 \%), \mathrm{TiO}_{2}(2.01 \%)$ and $\mathrm{MnO}(0.14 \%)$ present in the ball clay. The refractory properties of the locally produced crucibles are summarized in Figures 6-9.

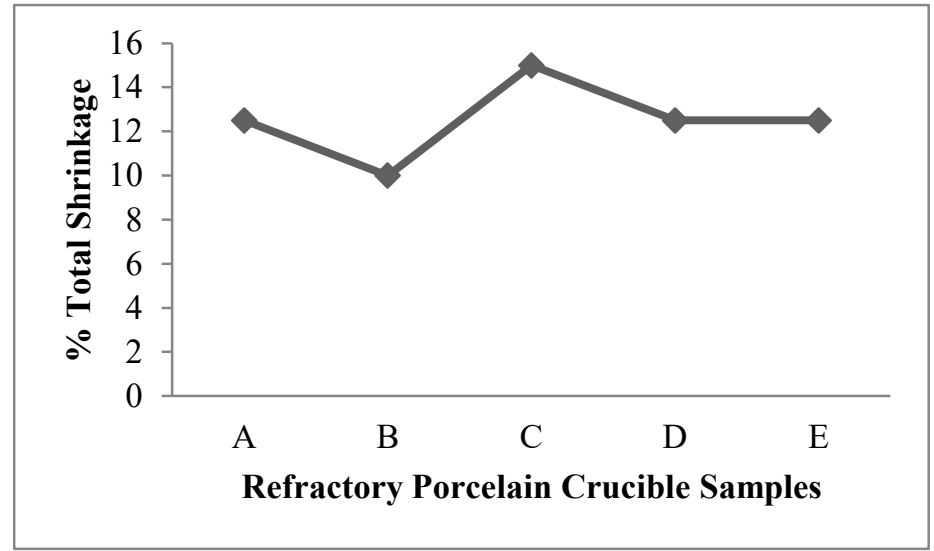

Fig. 6. Graph of $\%$ total shrinkage of the refractory porcelain crucibles 


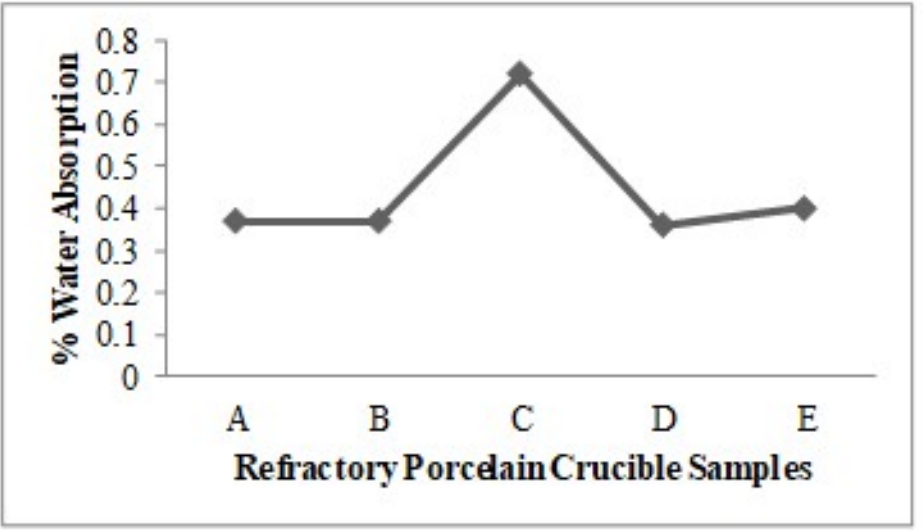

Fig. 7. Graph of $\%$ water absorption of the refractory porcelain crucibles

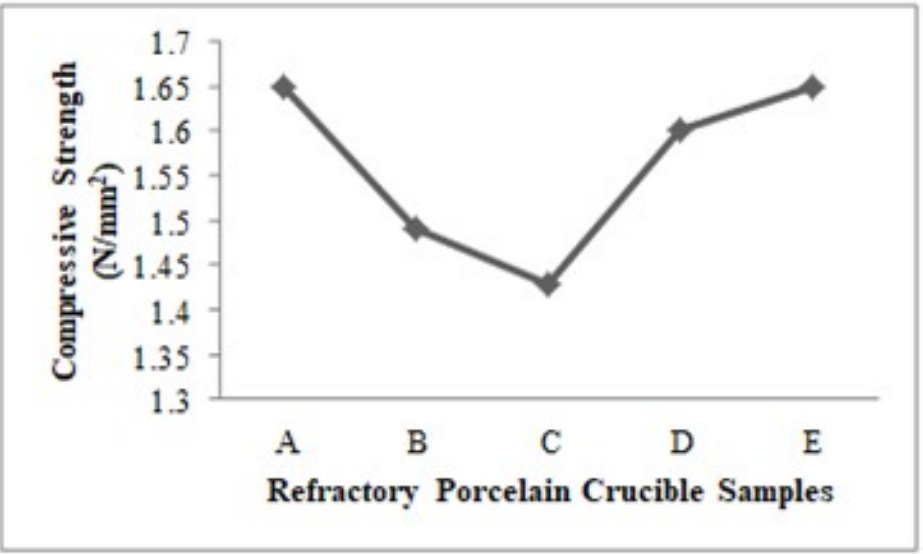

Fig. 8. Graph of compressive strength of the refractory porcelain crucibles

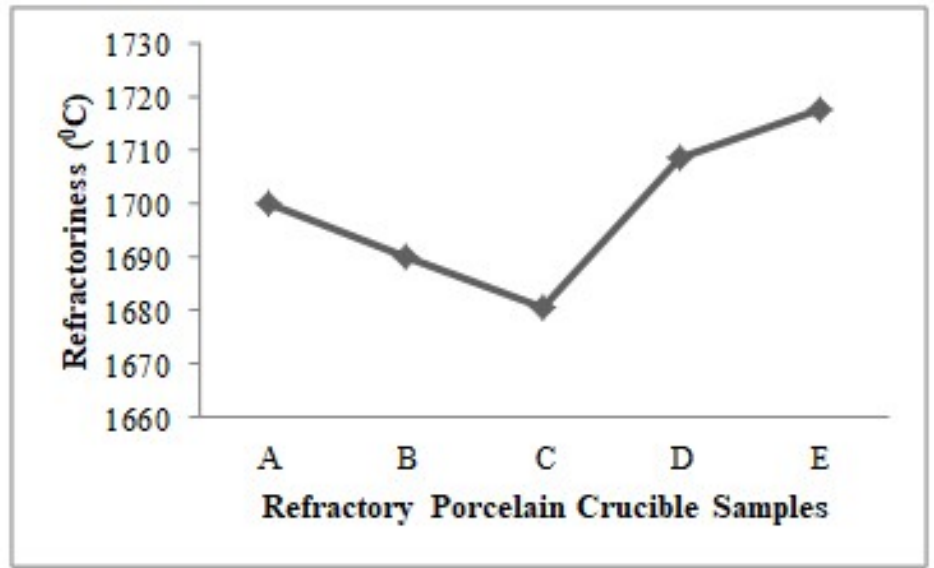

Fig. 9. Graph of refractoriness of the refractory porcelain crucibles 
Figure 6 and 7 show that the refractory crucible samples A, B, C,D and E have total shrinkage of $12.5 \%$, $10 \%, 15 \%, 12.5 \%$ and $12.5 \%$ and water absorption of $0.37 \%, 0.37 \%, 0.72 \%, 0.36 \%$ and $0.4 \%$ respectively. The values of $10 \%-15 \%$ total shrinkage and $0.36 \%-0.72 \%$ water absorption fall within recommended values of $14-15 \%$ total shrinkage and $0-0.5 \%$ water absorption for porcelain ceramic bodies fired up to cone 9 $\left(1260^{\circ} \mathrm{C}\right)$ according to [34]. Figure 8 shows that the values of compressive strength the refractory crucible samples A, B, C, D and E are $1.65 \mathrm{~N} / \mathrm{mm}^{2}, 1.49 \mathrm{~N} / \mathrm{mm}^{2}, 1.43 \mathrm{~N} / \mathrm{mm}^{2}, 1.60 \mathrm{~N} / \mathrm{mm}^{2}$ and $1.65 \mathrm{~N} / \mathrm{mm}^{2}$ respectively.

Figure 9 shows that the refractoriness for the refractory crucible samples A, B, C, D and E are $1700.00 \mathrm{C}$, $1690.1^{\circ} \mathrm{C}, 1680.2^{\circ} \mathrm{C}, 1708.8^{\circ} \mathrm{C}$ and $1717.5^{\circ} \mathrm{C}$ respectively. Sample $\mathrm{E}$ showed the highest value of refractoriness of $1717.5^{\circ} \mathrm{C}$, followed by sample $\mathrm{D}$ with the refractoriness of $1708.8^{\circ} \mathrm{C}$. This could be as a result of high content of calcined kaolin of $40 \mathrm{wt} \%$ and $50 \mathrm{wt} \%$ in sample D and E respectively. According to [27], higher content of grog gives better refractory properties. In samples A, B and C which all have $30 \mathrm{wt} \%$ calcined kaolin, the value of refractoriness seemed to have been compensated for by the percentage by weight of kaolin. There is gradual decrease in refractoriness from sample A to $\mathrm{C}$ with decrease in wt $\%$ of kaolin. This implies that calcined kaolin as well as kaolin is highly responsible for the value of refractoriness of porcelain crucibles.

\section{Conclusion}

Locally available ceramic raw materials from Ikere Ekiti clays and Awo quartz (locations in South Western Nigeria) show the physical and chemical properties expected of good aluminosilicate refractory materials. These ceramic resources are thus suitable for producing technical items used in high temperature applications and other viable ceramic products that can be used as close substitutes to the imported ones. The physical, mechanical and thermal properties of the produced crucibles show that they are of good quality and are suitable for use in high temperature applications. It was ascertained that four blended ceramic raw materials which include kaolin, ball clay, kaolin grog and quartz mixed in different percentage by weight are suitable for the production of refractory porcelain crucibles. Local exploration and exploitation of the abundant ceramic resources in Nigeria can help in saving cost required for procuring refractories such as porcelain crucibles and can also help to reduce the rate of unemployment in the country. Comparative study on the locally-produced and imported porcelain refractory crucibles in terms of quality assurance should be an area for further research.

\section{References}

[1] Olasupo, O. A. and Borode, J. O., Development of insulating refractory ramming mass from some Nigerian refractory raw materials. Journal of Minerals \& Materials Characterization \& Engineering. 2009; 8 (9): 667-678.

[2] Torres, M.M., Freestone, I.C., Hunt, A., and Rehren, T., Mass-produced mullite crucibles in medieval Europe: manufacture and material properties. J. Am. Ceram. Soc. 2008; 91 (6): 2071-2074.

[3] Söderberg, A., Metallurgic ceramics as a key to Viking Age Workshop Organization. Journal of Nordic Archaeological Science. 2004; 14:115-124.

[4] WiseGeek, What is a ceramic crucible? 2015. Available from: m.wisegeek.com/what-is-a-ceramic-crucible.htm

[5] Ovri J.E.O. and Onuoha C., Characterization of some Nigerian local clays for electrical porcelain applications. International Journal of Advanced Materials Research. 2015; 1 (3): 113-119. 
[6] Oladiji, A.O., Borode, J.O., Adewuyi, B.O., and Ohijeagbon, I.O., Development of porcelain insulators from locally sourced materials. USEP: Journal of Research Information in Civil Engineering. 2010; 7 (1): 47-58

[7] Cuesta L.C.D. and Bernardo S.T., Development of porcelain chemical crucibles from local materials. The Philipines Journal of Science. 1987; 116 (3): 327- 346.

[8] Schwartz M.A., White G.D. and Curtis C.E., Crucible handbook. United States Atomic Energy Commission. Oak Ridge National Laboratory. Oak Ridge, Tennessee; 1953.

[9] Nwobi B.E., Beneficiation of Bauchi graphite for crucible production. Master thesis, Department of Chemical Engineering Faculty of Engineering, Ahmadu Bello University, Zaria; 2006.

[10] Aye, A.E. and Oyetunji, A., Metallurgical analysis of Ugunoda clay deposit, Nigeria for use as a refractory. International Journal of Science and Advanced Technology. 2013; 3 (10): 25-29.

[11] Apeh F.I., Esezobor D.E., and Lawal G.I., Characterization of Onibode and Owode-ketu clays for use as refractory materials in foundry industry. Journal of Engineering Research. 2011; 16 (3):69-77.

[12] Umaru M., Aliyu M.A, Mohammed I.A., and Sadiq M.M., A Comparative study on the refractory properties of selected clays in North Central Nigeria. Academic Research International. 2012; 3 (1): 393-398.

[13] Lawrence O.O. and Ayo S.A., Suitability of Nigerian rocks as refractory materials for monolithic furnace lining. Particulate Science and Technology: An International Journal. 2012; 30 (3): 209-219.

[14] Aigbodion, V.S. et al, Production of alumino-silicate clay-bonded bagasse ash composite crucible by slip casting, J. Mater. Environ. Sci. 2014; 5 (5): 1658-1666.

[15] Garkida A.D., Local raw material exploration for the production of refractory pots for melting glass. Master Thesis, Department of Industrial Design, Faculty of Environmental Design, Ahmadu Bello University, Zaria; 1998.

[16] Adamu A., Giwa Y., and Opoku E.V., Production of High Temperature Refractory Crucibles from Locally Available Clays in Nigeria. Proceedings to the 12th Annual Ceramic Researchers Association of Nigeria (CERAN) Conference and Exhibition held at Auchi Polytechnic, Auchi on 4th-8th October, 2015.

[17] Monteiro R.R., Sabioni, A.C.S., da Costa G.M., Preparation of mullite from topaz. Cerâmica. 2004; 50 (316): 318-323.

[18] Chen C.Y., Lan G.S., and Tuan W.H., Microstructural evolution of mullite during the sintering of kaolin powder compacts. Ceramics International. 2000; 26: 715-720.

[19] Ruan G., Zhang Z., Yin M., and Xu G., Effect of aluminum powder on the synthesis of corundum-mullite composites. Ceramics - Silikáty. 2013; 57 (2): 133-137.

[20] Kashim I.B., Solid mineral development in sustaining Nigeria's economic and environmental realities of the 21 st Century. Journal of Sustainable Development in Africa. $2011 \mathrm{a} ; 13$ (2): 210-223.

[21] Adindu, C.I., Moses, J., Thaddeus, C.A., and Tse D.T., Exploring ceramic raw materials in Nigeria and their contribution to nation's development. American Journal of Engineering Research. 2014; 3 (9): 127-134.

[22] Afolabi O., Olorunfemi M.O., Olagunju A.O. and Afolayan J.F., Resource quantification of a kaolin deposit using the electrical resistivity method- case study from Ikere Ekiti, SouthWest, Nigeria. Ife Journal of Science. 2004; 6 (1): 35-40. 
[23] Atanda, P.O., Oluwole, O.O., and Oladeji. T.A., Electrical porcelain production from selected Kaolin deposits in South Western Nigeria using slip casting. International Journal of Materials and Chemistry. 2012: 2 (3): 86-89.

[24] Jimoh M.T., Petrochemical studies of pegmatites around Awo, South Western Nigeria. Journal of Environmental Issues and Agriculture in Developing Countries. 2011; 3(2): 19-32.

[25] Kashim I.B., The place of ceramics today. CeramicsTECHNICAL. 2011b; 32: 89-94.

[26] American Elements. Kaolin. 2015. Accessed from: www.americanelements.com/kaolin

[27] Henrik N., The self-reliant potter: refractories and kilns. 1987. Available from: www.nzdl.org/gsdlmod.

[28] Zauro T.D.M., An evaluation of the suitability of some ceramic raw materials in Kebbi State for the production of porcelain for tableware. Journal of Industrial Design. 2010; 1:43-53.

[29] Gamelasa J.A.F., Ferrazb E. and Rochaca F., An insight into the surface properties of calcined kaolinitic clays: the grinding effect, colloids and surfaces A. Physicochem. Eng. Aspects. 2014; 455: 49-57.

[30] Hansen T., Formulating a porcelain. 2008. Available from: https://digitalfire.com/formulating_a_porcelain_282.html.

[31] Imerys Refractory Minerals, Calcined kaolin. 2015. Available from: www.imerysrefractoryminerals.com

[32] Odewale I.O., Obika B.M. and Tse D.T., Production and characterization of aluminosilicate refractory brick using Unwana Beach silica sand, Ekebedi and Unwana clays. British Journal of Applied Science \& Technology. 2015; 5(5): 461-471.

[33] Atta A.Y., Ajayi O.A. and Adefila S.S., Synthesis of Faujasite Zeolites from Kankara Kaolin Clay. Journal of Applied Sciences Research. 2007; 3 (10): 1017-1021.

[34] Zamek, J., Clay Body Shrinkage and Absorption. Online Journal of Ceramic Industry. 2003. Available from: www.ceramicindustry.com 


\section{Authors' Profiles}
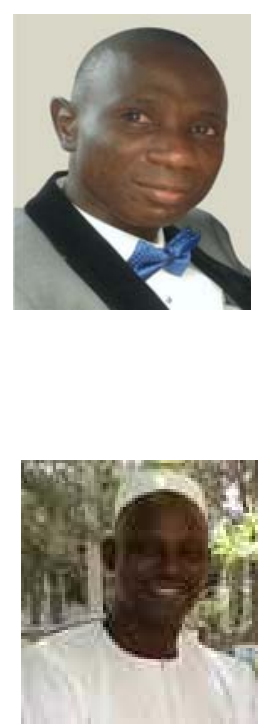

Kashim Isah Bolaji is a professor in the Department of Industrial Design, Federal University of Technology Akure, Ondo State, Nigeria. He has taught ceramics in polytechnics and the Federal University of Technology, Akure for over two decades. He is a member of the following professional associations: Association of African Industrial Designers (AAID), Craft Potters Association of Nigeria (CPAN) and Ceramics Researchers Association of Nigeria (CeRAN) among others.



Akinbogun Tolulope Lawrence is a professor in the Department of Industrial Design, Federal University of Technology, Akure Nigeria. Being a pioneering staff of the Department of Industrial Design, he has taught ceramics at the University since 1992 . He is a member of the following professional associations: Ceramic Researchers Association of Nigeria (CeRAN), Craft Potters Association of Nigeria (CPAN), American Ceramic Society (ACerS) and International Society of Ceramic Art Education and Exchange (ISCAEE) among others.

How to cite this paper: Odewole, Peter Oluwagbenga, Kashim, Isah Bolaji, Akinbogun, Tolulope Lawrence. " Production of Refractory Porcelain Crucibles from Local Ceramic Raw Materials using Slip Casting ", International Journal of Engineering and Manufacturing(IJEM), Vol.9, No.5, pp.56-69, 2019. DOI: 10.5815/ijem.2019.05.05 